\title{
Thermal behavior of glycolic acid, sodium glycolate and its compounds with some bivalent transition metal ions in the solid state
}

\author{
A. L. C. S. do Nascimento ${ }^{1}$ J. A. Teixeira ${ }^{1}$ W. D. G. Nunes ${ }^{1}$ - D. J. C. Gomes ${ }^{2}$

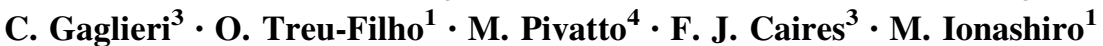

Received: 25 June 2016/ Accepted: 6 February 2017/Published online: 20 February 2017

(C) Akadémiai Kiadó, Budapest, Hungary 2017

\begin{abstract}
Synthesis, characterization and thermal behavior of some transition metal glycolates, $\mathrm{M}\left(\mathrm{C}_{2} \mathrm{H}_{3} \mathrm{O}_{3}\right)_{2}$ $[\mathrm{M}=\mathrm{Mn}(\mathrm{II}), \mathrm{Co}(\mathrm{II}), \mathrm{Ni}(\mathrm{II}), \mathrm{Cu}(\mathrm{II})$ and $\mathrm{Zn}(\mathrm{II})]$, as well as the thermal behavior of glycolic acid and its sodium salt $\left(\mathrm{NaC}_{2} \mathrm{H}_{3} \mathrm{O}_{3}\right)$ were investigated employing simultaneous thermogravimetry and differential thermal analysis, infrared spectroscopy (FTIR), simultaneous thermogravimetrydifferential scanning calorimetry coupled to FTIR (evolved gas analysis), complexometry and high-resolution electrospray ionization mass spectrometry. The lowest energy model structure of each complex has been proposed by using the density functional theory at the B3LYP/6$311++\mathrm{g}(\mathrm{d})$ level of theory. The results provided information concerning the composition, dehydration, thermal stability, thermal decomposition and identification of the gaseous products evolved during the thermal decomposition of these compounds in dynamic dry air atmosphere.
\end{abstract}

Electronic supplementary material The online version of this article (doi:10.1007/s10973-017-6161-3) contains supplementary material, which is available to authorized users.

F. J. Caires

caires.flavio@fc.unesp.br

1 Departamento de Química Analítica, Instituto de Química, UNESP- Univ Estadual Paulista, Campus de Araraquara, Araraquara, SP, Brazil

2 Instituto Federal do Piauí, Campus Paulistana, Paulistana, PI, Brazil

3 Departamento de Química, FACULDADE DE CIÊNCIAS, UNESP_Univ. Estadual Paulista, Campus Bauru, Bauru, SP, Brazil

4 Instituto de Química, Universidade Federal de Uberlândia, Uberlândia, MG, Brazil
Keywords Bivalent transition metals - Glycolate . Thermal analysis - DFT

\section{Introduction}

Glycolic acid is a carboxylic acid and lower structurally representative of the class of alpha hydroxy acids (compounds that present a carboxyl and a hydroxyl group in the alpha position), molecular formula $\mathrm{C}_{2} \mathrm{H}_{4} \mathrm{O}_{3}$. As it has two functional groups in the same structure, $\mathrm{OH}$ and $-\mathrm{COOH}$, the molecule can act as a versatile ligand in coordination chemistry. In the study of coordination compounds, thermal analysis techniques are powerful characterization tools, making it possible to understand their thermal behavior, hydrate formation, thermal stability, existence of polymorphs, composition, intermediates and so on $[1,2]$. Therefore, conducting the thermal study of metal complexes is a fundamental step before proposing technological applications of these compounds.

Several studies involving the synthesis, crystal structures, thermal decomposition of metal glycolate $\left(\mathrm{C}_{2} \mathrm{H}_{3} \mathrm{O}_{3}^{-}\right)$, as well as the use of these compounds as precursors in other syntheses have been described. These researches reported a structural study of the orthorhombic tris-glycolates of lanthanum (III) and gadolinium (III) [3]; complexing the trivalent $\mathrm{Am}, \mathrm{Cm}$ and $\mathrm{Bk}$ ions by glycolate [4]; manganese (II)/(III) glycolates; preparation, X-ray crystallographic study and application in radical cycloaddition reactions [5]; synthesis and structure of two cerium complexes with mixed-ligands oxalate and glycolate [6]; zinc glycolate: a precursor to $\mathrm{ZnO}$ [7]; synthesis of MWCNT/nickel glycolate polymer core-shell nanostructures and their nonenzymatic 
electrocatalytic activity toward glucose [8]; thermal decomposition and spectroscopic investigation of a new aqueous glycolato(-peroxo) Ti(IV) solution-gel precursor [9]; and assembly of three coordination polymers from glycolate ligands: synthesis, crystal structures and thermal properties [10].

This paper presents the synthesis of compounds of glycolic acid with bivalent transition metal ions (Mn, Co, $\mathrm{Ni}, \mathrm{Cu}$ and $\mathrm{Zn}$ ) and its characterization by using different analytical techniques in order to study its thermal behavior.

\section{Experimental}

\section{Synthesis}

The glycolic acid $\left(\mathrm{C}_{2} \mathrm{H}_{4} \mathrm{O}_{3}, \mathrm{HL}\right)$ with $99 \%$ purity was obtained from Sigma-Aldrich and used without any additional purification. Bivalent manganese, cobalt, nickel, copper and zinc carbonates were prepared by adding slowly with continuous stirring saturated sodium hydrogen carbonate solution to the corresponding metal chlorides (or sulfate for copper solutions) $(50.0 \mathrm{~mL}$, $0.1 \mathrm{~mol} \mathrm{~L}^{-1}$ ) until quantitative precipitation of the metal ions. The precipitates were washed with distilled water for elimination of chloride or sulfate ions (qualitative test with $\mathrm{AgNO}_{3} / \mathrm{HNO}_{3}$ solution for chloride and $\mathrm{BaCl}_{2}$ solution for sulfate) and maintained in aqueous suspension.

Solid-state $\mathrm{Mn}(\mathrm{II}), \mathrm{Co}(\mathrm{II}), \mathrm{Ni}(\mathrm{II}), \mathrm{Cu}(\mathrm{II})$ and $\mathrm{Zn}(\mathrm{II})$ compounds were prepared by mixing the corresponding metal carbonate aqueous suspension with a slight excess of glycolic acid solution $\left(0.15 \mathrm{~mol} \mathrm{~L}^{-1}\right)$ and slowly heated to near ebullition until total neutralization of the metal carbonate. The volume of resulting solutions was reduced by evaporation to $20 \mathrm{~mL}$ (no precipitate was observed), and then, ethanol was added, which caused the precipitation of the compounds.

The formed precipitates were filtered, washed five times with ethanol to eliminate the excess of glycolic acid, dried at $50{ }^{\circ} \mathrm{C}$ in a forced air circulation oven during $24 \mathrm{~h}$ and kept in a desiccator over anhydrous calcium chloride until constant mass. Scheme of the synthesis and reactions involved is presented below:

Step $1 \mathrm{MCl}_{2}(a q)+2 \mathrm{NaHCO}_{3}(a q) \rightarrow \mathrm{M}\left(\mathrm{CO}_{3}\right)(s)+$ $2 \mathrm{NaCl}(a q)+\mathrm{CO}_{2}(g)+\mathrm{H}_{2} \mathrm{O}(l)$ (the carbonates were washed to remove the chloride or sulfate anions)

Step $2 \mathrm{M}\left(\mathrm{CO}_{3}\right)(s)+2 \mathrm{HL}(a q) \quad$ (slight excess) $\rightarrow$ $\left[\mathrm{M}(\mathrm{L})_{2}\right](a q)+3 \mathrm{CO}_{2}(g)+3 \mathrm{H}_{2} \mathrm{O}(l)+\mathrm{HL}$ (excess)

Step $3\left[\mathrm{M}(\mathrm{L})_{2}\right](a q)+\mathrm{HL}$ (excess) $\longrightarrow$ Ethanol $\left[\mathrm{M}(\mathrm{L})_{2}\right]$ $(s)+$ HL(ethanol) (Filtration, washing the precipitate to remove excess glycolic acid and drying the compounds)

\section{Characterization}

The solid-state metal ions, hydration water and glycolate contents were determined from TG curves. The metal ions were also determined by complexometry with standard EDTA solution after igniting the compounds to the respective oxides and their dissolution in hydrochloric acid solution $[11,12]$.

Carbon and hydrogen contents were determined by calculations based on the mass losses of the TG curves, since the thermal decomposition occurs with the formation of their respective oxides as the final residue, with known stoichiometry.

High-resolution electrospray ionization mass spectrometry (HRESIMS) was performed in an ultrOTOF (Bruker Daltonics) spectrometer, operating in the negative mode. Methanol/water $(1: 1, \mathrm{v} / \mathrm{v})$ was used as the solvent system, and the samples were infused into the ESI source at a flow rate of $5 \mathrm{~mL} \mathrm{~min}^{-1}$. The calculated values for the charged complex ions were made by using ChemDraw Ultra 14.0.

The X-ray powder diffraction patterns were obtained using a Siemens D-5000 X-ray diffractometer, employing CuK $\alpha$ radiation $(\lambda=1.541 \AA)$ and setting of $40 \mathrm{kV}$ and $20 \mathrm{~mA}$.

The attenuate total reflectance infrared spectra for glycolic acid, sodium glycolate and its metal ion compounds were run on a Nicolet iS10 FTIR spectrophotometer, using an ATR accessory with Ge window. The FTIR spectra were recorded with 32 scans per spectrum at a resolution of $4 \mathrm{~cm}^{-1}$.

Simultaneous TG-DTA curves were obtained with a thermal analysis system, model SDT 2960, from TA Instruments. The purge gas was air, with a flow rate of $100 \mathrm{~mL} \mathrm{~min}^{-1}$, a heating rate of $10{ }^{\circ} \mathrm{C} \mathrm{min}^{-1}$ and samples weighing about $7 \mathrm{mg}$. Alumina crucibles were used for recording the TG-DTA curves.

The identification of the evolved gaseous products was carried out using a Mettler Toledo Thermogravimetric Analyzer (TG-DSC) coupled to the Nicolet FTIR spectrometer equipped with a gas cell and DTGS KBr detector. The furnace and heated gas cell $\left(250{ }^{\circ} \mathrm{C}\right)$ were coupled through a heated $\left(T=200{ }^{\circ} \mathrm{C}\right) 120-\mathrm{cm}$ stainless steel transfer line with $3.0 \mathrm{~mm}$ diameter, both purged with dry air $\left(50 \mathrm{~mL} \mathrm{~min}^{-1}\right)$. The FTIR spectra were recorded with 16 scans per spectrum at a resolution of $4 \mathrm{~cm}^{-1}$.

\section{Computational strategy}

In this study, the employed quantum chemical approach to determine the molecular structures was Beck's three parameter hybrid theory [13] using the Lee-Yang-Parr correlation functional (B3LYP) [14], and the basis sets used for calculations were $6-311++\mathrm{g}(\mathrm{d})[15,16]$. The 
performed molecular calculations in this study were done using the Gaussian 09 routine [17]. The theoretical infrared spectrum was calculated using a harmonic field [18] based on $\mathrm{C}_{1}$ symmetry (electronic state ${ }^{1} \mathrm{~A}$ ). Frequency values (not scaled), relative intensities, assignments and description of vibrational modes are presented. The geometry optimization was computed using the optimized algorithm of Berny [19], and the calculations of vibrational frequencies were also implemented to determine an optimized geometry that constitutes minimum or saddle points. The principal infrared-active fundamental modes assignments and descriptions were made by the GaussView $5.0 .2 \mathrm{~W}$ graphics routine [20].

\section{Results and discussion}

\section{Glycolic acid}

The TG-DTA curves of glycolic acid are shown in Fig. 1. These curves show that the anhydrous compound is stable up to $79^{\circ} \mathrm{C}$ and above this temperature the mass losses occur in two consecutive steps between 79 and $400{ }^{\circ} \mathrm{C}$ (TG) with thermal events corresponding to these losses or due to physical phenomenon (DTA). The endothermic peak at $79^{\circ} \mathrm{C}$ is due to the melting, and the first mass loss between 79 and $200{ }^{\circ} \mathrm{C}(50.48 \%)$ corresponding to the endothermic event between 125 and $200{ }^{\circ} \mathrm{C}$ is attributed to the partial evaporation of the molten compound with the formation of carbonaceous residue, and this was confirmed from visual inspection on a melting point equipment. The mass loss between 200 and $400{ }^{\circ} \mathrm{C}$ $(49.52 \%)$ corresponding to an exothermic peak at $300{ }^{\circ} \mathrm{C}$ is attributed to the oxidation of the organic matter and/or of the gaseous products evolved in this step.

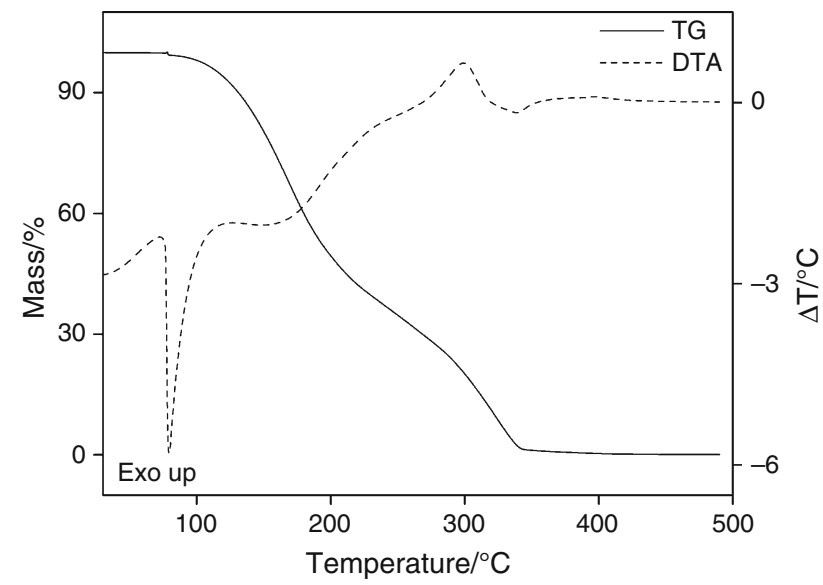

Fig. 1 Simultaneous TG-DTA curves $(9.2532 \mathrm{mg})$ of the glycolic acid

\section{Sodium glycolate}

The TG-DTA curves of anhydrous sodium glycolate are shown in Fig. 2. These curves show mass losses in two steps and thermal events corresponding to these losses or due to physical phenomenon. The sharp endothermic peak at $217^{\circ} \mathrm{C}$ is attributed to the melting of the compound, which was confirmed in a melting point apparatus. The small sudden apparent mass loss observed during the melting of the compound undoubtedly is due to the transformation of the pulverized solid compound to liquid state. When the sample was heated up to $217^{\circ} \mathrm{C}$, cooled to ambient temperature and heated again, no mass loss was observed during the fusion, as shown in Fig. $2 b$.

The first mass loss between 217 and $355^{\circ} \mathrm{C}(27.44 \%)$ corresponds to the thermal decomposition and oxidation of the organic matter with the formation of carbonaceous residue, confirmed from visual inspection of the sample heated to that temperature. No thermal event is observed in the beginning of the mass loss, probably because up to $300{ }^{\circ} \mathrm{C}$, endothermic and exothermic reactions might be occurring simultaneously and the net heat is not sufficient to produce a thermal event.

The second mass loss between 355 and $477{ }^{\circ} \mathrm{C}(18.22 \%)$ corresponding to the sharp exothermic peak at $476{ }^{\circ} \mathrm{C}$ is attributed to the oxidation of the carbonaceous residue and/ or of the gaseous products evolved during the thermal decomposition. The total mass loss up to $477{ }^{\circ} \mathrm{C}$ is in agreement with the formation of sodium carbonate (Theor. $=45.95 \%$; $\mathrm{TG}=45.66 \%$ ). Tests with hydrochloric acid solution on sample heated up to the temperature

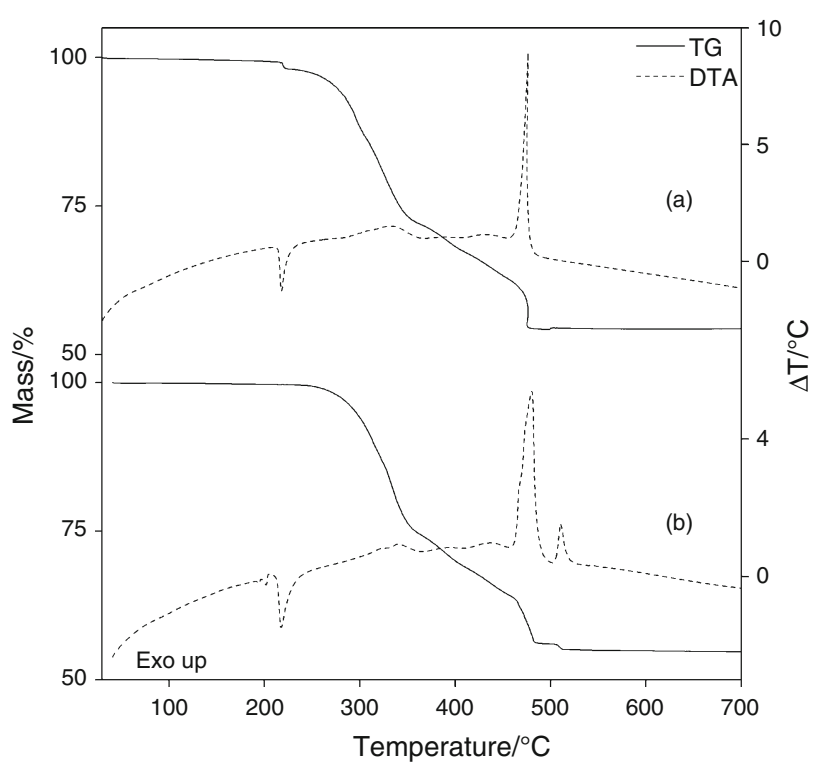

Fig. 2 Simultaneous TG-DTA curves of the sodium glycolate (a) $3.2770 \mathrm{mg}$ and (b) $3.0570 \mathrm{mg}$ 
indicated by the TG-DTA curves $\left(477^{\circ} \mathrm{C}\right)$ confirmed the formation of sodium carbonate.

\section{Transition metal complexes}

\section{Analytical results}

To the synthesized compounds, the analytical and thermoanalytical (TG) data are shown in Table 1 . These results permitted to establish the stoichiometry of these compounds, which are in agreement with the general formula $\left[\mathrm{M}(\mathrm{L})_{2}\right]$ where $\mathrm{M}$ represents $\mathrm{Mn}(\mathrm{II}), \mathrm{Co}(\mathrm{II}), \mathrm{Cu}(\mathrm{II})$ and $\mathrm{Zn}(\mathrm{II}), \mathrm{L}$ is glycolate, except for Ni (II) presenting the general formula $\left[\mathrm{Ni}\left(\mathrm{L}_{2}\right)\right] \cdot 0.25 \mathrm{H}_{2} \mathrm{O}$.

\section{Mass spectrometric analyses}

High-resolution mass spectra of the glycolate complexes are presented in supplementary material (Figs S1 to S5). These spectra show peaks at $\mathrm{m} / \mathrm{z} 203.9475,207.9423$, 206.2441, 212.9472 and 212.9383 correspond to the molecular ions $[\mathrm{M}-\mathrm{H}]^{-}\left(\left[\mathrm{Mn}\left(\mathrm{C}_{2} \mathrm{H}_{3} \mathrm{O}_{3}\right)_{2}-\mathrm{H}\right]^{-},\left[\mathrm{Co}\left(\mathrm{C}_{2} \mathrm{H}_{3-}\right.\right.\right.$ $\left.\left.\mathrm{O}_{3}\right)_{2}-\mathrm{H}\right], \quad\left[\mathrm{Ni}\left(\mathrm{C}_{2} \mathrm{H}_{3} \mathrm{O}_{3}\right)_{2}-\mathrm{H}\right]^{-}, \quad\left[\mathrm{Cu}\left(\mathrm{C}_{2} \mathrm{H}_{3} \mathrm{O}_{3}\right)_{2}-\mathrm{H}\right]^{-}$and $\left.\left[\mathrm{Zn}\left(\mathrm{C}_{2} \mathrm{H}_{3} \mathrm{O}_{3}\right)_{2}-\mathrm{H}\right]^{-}\right)$, which confirms the $1: 2 \mathrm{metal} / \mathrm{glyco}-$ late composition and it is in accordance with the minimum formula determined by other analytical methods (TG and EDTA). Mass spectra of the complexes are typical for their isotopic pattern, as can be exemplified in the mass spectrum of the zinc complex, where the signals $(\mathrm{m} / \mathrm{z})$ correspond to the isotopes ${ }^{64} \mathrm{Zn}(48.6 \%),{ }^{66} \mathrm{Zn}(27.9 \%),{ }^{67} \mathrm{Zn}$ (4.1\%), ${ }^{68} \mathrm{Zn}(18.8 \%)$ and ${ }^{70} \mathrm{Zn}(0.6 \%)$ isotopes, with the nuclide abundance in parentheses.

\section{$X R D$}

The X-ray patterns (supplementary material, Fig S6) show that all compounds have crystalline structure and that cobalt, nickel and copper compounds show evidence for formation of isomorphous series. The crystallinity of these compounds follows the order:

$\mathrm{Cu}>\mathrm{Ni}>\mathrm{Zn}>\mathrm{Mn} \approx \mathrm{Co}$.
The difference in the crystallinity of these compounds may be due to the conditions of precipitation, since the solid compounds are obtained by heating the solution to near its ebullition temperature and the heating, as well as the time of ebullition was not controlled.

\section{Infrared vibrational spectroscopy and theoretical calculations}

To determine the probable structures of the complex, theoretical calculations have been performed, since numerous attempts to obtain single crystals were not successful. The optimized geometries of the lower energy isomer are shown in Fig. 3, and the other structures of the higher energy isomers and further details around the coordinating sphere (angles and bonding lengths) can be found in the supplementary material. Three isomers are proposed for each complex: the first with ligands coordinated by hydroxyl group and by one oxygen atom of the carboxylate group forming a five-membered ring in trans configuration (isomer A); the second as isomer A but in the cis configuration (isomer $\mathrm{B}$ ); and the third presenting ligands coordinated only by the carboxylate group (isomer C). Isomer A (trans) is the most stable for $\mathrm{Mn}$, Co and Ni complexes, while for $\mathrm{Cu}$ and $\mathrm{Zn}$ complexes, isomer $\mathrm{C}$ is the most stable. The structures of isomer B (cis) to the complex of $\mathrm{Mn}$ and $\mathrm{Zn}$ were not optimized.

From the structures of the isomers $\mathrm{A}$ and $\mathrm{C}$, theoretical infrared vibrational spectra were generated and then compared with the experimental data (Fig. 4). These results show that the theoretical vibrational spectra of the isomer $\mathrm{C}$ for all compounds are very similar to the experimental spectra even though for the Mn, Co and Ni complexes the theoretical results show that the most probable structure is the isomer A, since it has the lowest energy. These differences are probably associated to the fact that calculations were performed considering isolated individual molecules of the complex, while the experimental data were obtained in the solid state, in which there are many intermolecular interactions.

Table 1 Analytical and thermoanalytical (TG) data for the $\left[\mathrm{M}(\mathrm{L})_{2}\right]$ compounds

\begin{tabular}{|c|c|c|c|c|c|c|c|c|c|c|c|c|}
\hline \multirow[t]{2}{*}{ Complexes } & \multicolumn{3}{|c|}{ Metal oxide/\% } & \multicolumn{2}{|c|}{$\mathrm{L}($ lost $) / \%$} & \multicolumn{2}{|c|}{ Water/\% } & \multicolumn{2}{|l|}{$\mathrm{C} / \%$} & \multicolumn{2}{|l|}{$\mathrm{H} / \%$} & \multirow[t]{2}{*}{ Final residue } \\
\hline & Calc. & EDTA & TG & Calc. & TG & Calc. & TG & Calc. & E.A. & Calc. & E.A. & \\
\hline$\left[\mathrm{Mn}(\mathrm{L})_{2}\right]$ & 37.21 & 37.07 & 37.21 & 62.79 & 62.79 & & & 23.43 & 23.43 & 2.96 & 2.96 & $\mathrm{Mn}_{3} \mathrm{O}_{4}$ \\
\hline$\left[\mathrm{Co}(\mathrm{L})_{2}\right]$ & 35.83 & 35.42 & 35.64 & 64.17 & 64.36 & & & 22.97 & 23.04 & 2.90 & 2.91 & $\mathrm{CoO}$ \\
\hline$\left[\mathrm{Ni}(\mathrm{L})_{2}\right] \cdot 0.25 \mathrm{H}_{2} \mathrm{O}$ & 35.03 & 35.05 & 35.03 & 64.97 & 64.97 & 2.13 & 2.13 & 22.52 & 22.52 & 3.08 & 3.08 & $\mathrm{NiO}$ \\
\hline$\left[\mathrm{Cu}(\mathrm{L})_{2}\right]$ & 37.24 & 37.06 & 36.89 & 62.76 & 63.11 & & & 22.49 & 22.61 & 2.84 & 2.85 & $\mathrm{CuO}$ \\
\hline$\left[\mathrm{Zn}(\mathrm{L})_{2}\right]$ & 37.77 & 37.89 & 37.51 & 62.23 & 62.49 & & & 22.30 & 22.39 & 2.81 & 2.82 & $\mathrm{ZnO}$ \\
\hline
\end{tabular}

$L$ glycolate 
Fig. 3 Theoretical 3D structure of lower energy of the complexes

Isomer $\mathrm{A}$
$\operatorname{trans}-\left[\mathrm{Mn}(\mathrm{L})_{2}\right]$
$-1.10353674 \times 10^{6} \mathrm{kcal} \mathrm{mol}^{-1}$
Isomer $\mathrm{A}$
trans-[Co $\left.(\mathrm{L})_{2}\right]$
$-1.24899513 \times 10^{6} \mathrm{kcal} \mathrm{mol}^{-1}$

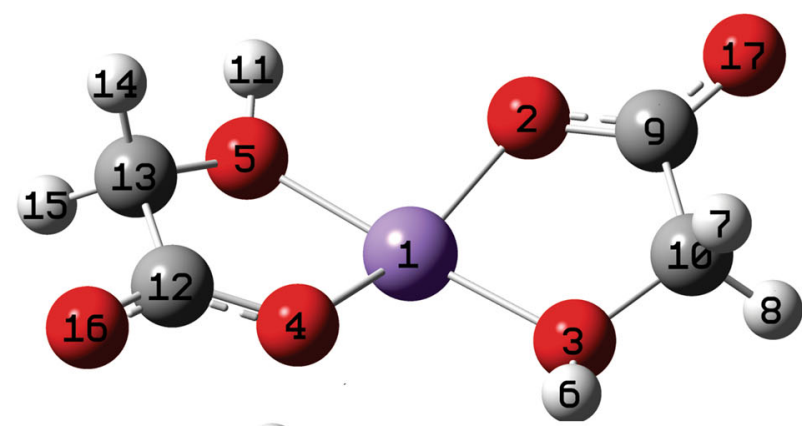

Isomer $A$
trans- $\left[\mathrm{Ni}(\mathrm{L})_{2}\right]$
$-1.32777092 \times 10^{6} \mathrm{kcal} \mathrm{mol}^{-1}$

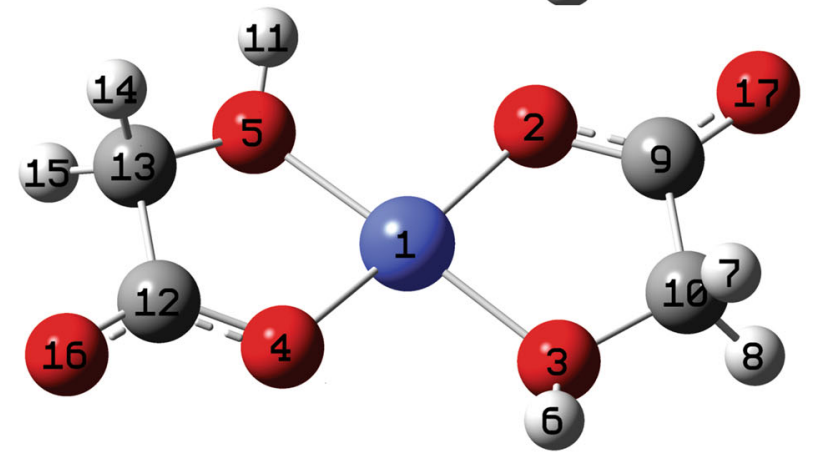

Isomer $\mathrm{C}$
$\left[\mathrm{Cu}(\mathrm{L})_{2}\right]$
$-1.41071753 \times 10^{6} \mathrm{kcal} \mathrm{mol}^{-1}$
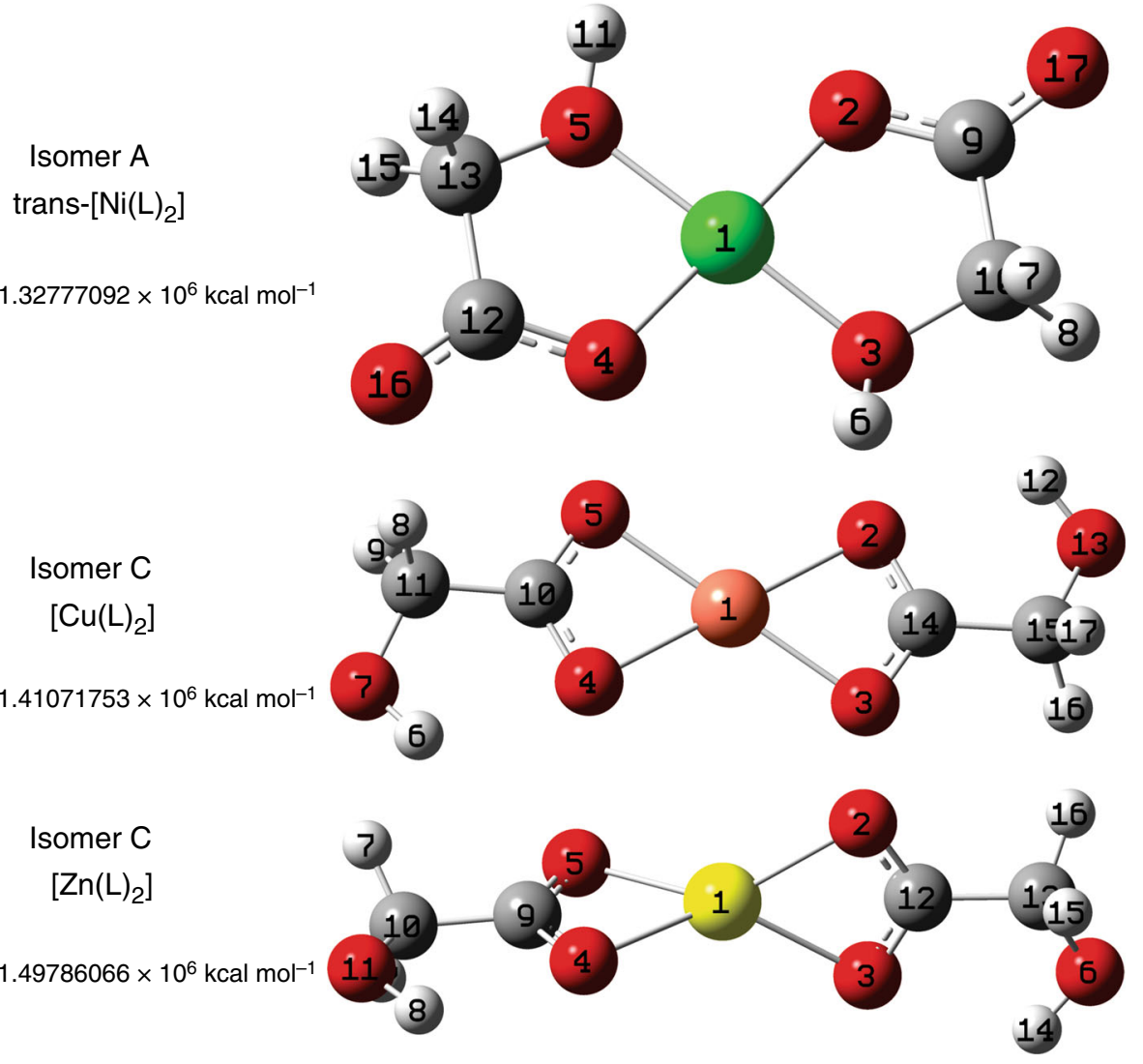

The main frequencies of the IR spectra of glycolic acid, sodium salt and complex were assigned based on the calculated spectra for the isomer $\mathrm{C}$ and are presented in Table 2. For sodium glycolate, the bands centered at $1594 \mathrm{~cm}^{-1}$ and $1383 \mathrm{~cm}^{-1}$ were assigned to antisymmetric $\left(v_{\mathrm{as}} \mathrm{COO}^{-}\right)$and symmetric $\left(v_{\mathrm{s}} \mathrm{COO}^{-}\right)$carboxyl stretching frequencies, respectively $[21,22]$. The values of $\Delta v$ $\left(v_{\text {as }} \mathrm{COO}^{-}-v_{\mathrm{s}} \mathrm{COO}^{-}\right.$, carboxylate vibrations) for the synthesized compounds are smaller than those ones calculated for the sodium salt (Table 2), suggesting that the coordination is carried out through the carboxylate group of the glycolate in a bidentate mode (chelating and/or bridging 

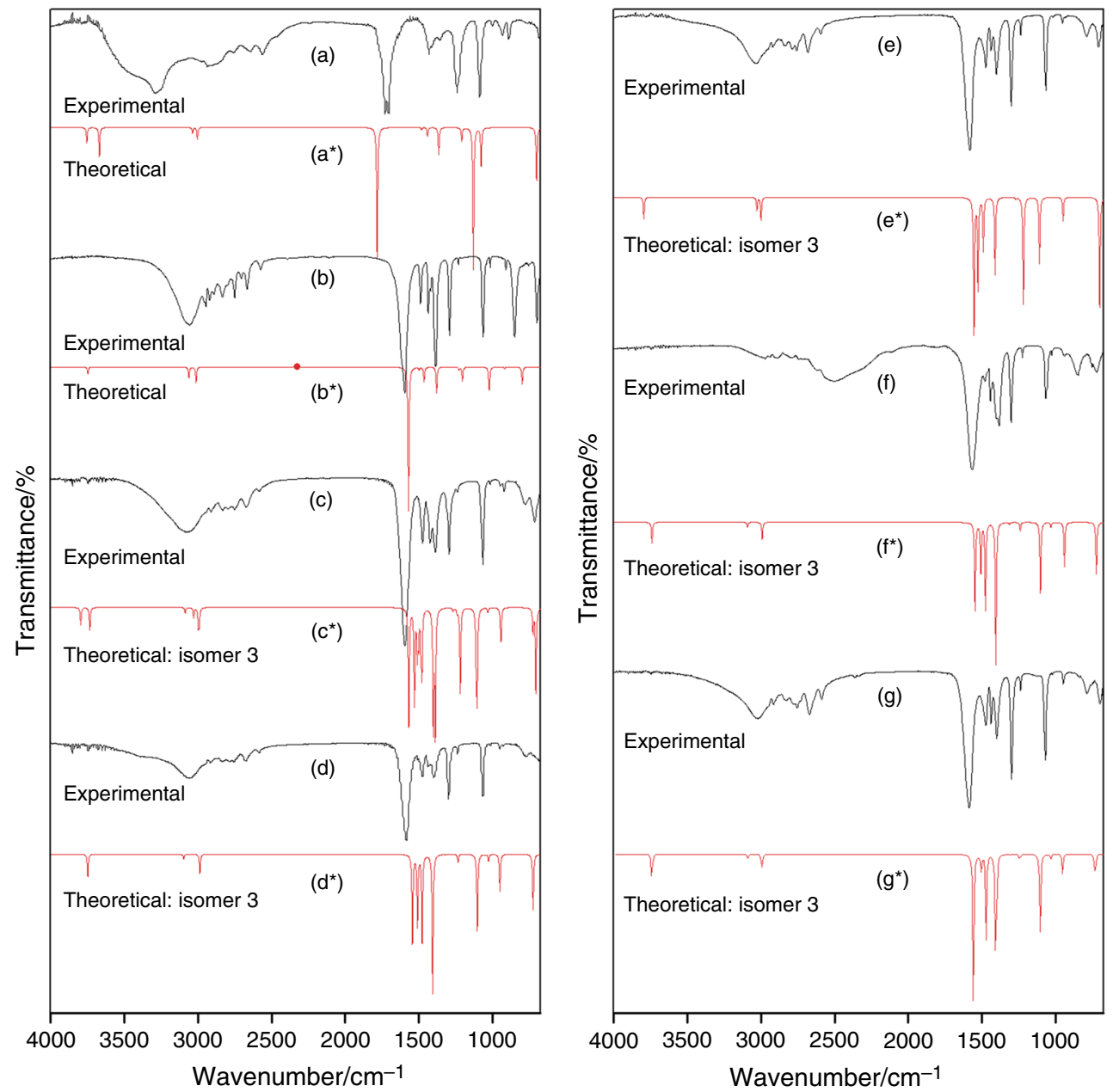

Fig. 4 Experimental and theoretical ${ }^{*}$ infrared spectra of $(a)$ glycolic acid $(b)$ sodium glycolate and $(c, d, e, f$ and $g)$ complexes of bivalent transition metals

ligand) [23], in accordance with the results of the theoretical calculation. On the other hand, the results of Table 2 show that the $v(\mathrm{C}-\mathrm{OH})$ is shifted toward lower energy than those observed in the glycolic acid, suggesting that metal ion can be coordinated by the hydroxyl group which is also in agreement with the literature $[24,25]$ and the results of the theoretical calculation for the compounds of $\mathrm{Mn}, \mathrm{Co}$ and $\mathrm{Ni}$. Thus, these results reinforce the conclusion that the coordination of ligand is carried out through the oxygen atoms of the carboxylate and the hydroxyl groups.

\section{Thermal analysis (TG-DTA and EGA)}

Manganese compound The simultaneous TG-DTA curves are shown in Fig. 5a. The thermal decomposition of the anhydrous compound occurs in three overlapping steps, between 100-270, 270-317 and 317-400 ${ }^{\circ} \mathrm{C}$ with losses of $9.30,11.60$ and $41.89 \%$, respectively, corresponding to an endothermic peak at $270{ }^{\circ} \mathrm{C}$ and an exothermic one at $400{ }^{\circ} \mathrm{C}$, which are attributed to thermal decomposition and oxidation of the organic matter, respectively. No thermal event corresponding to second step is observed in the DTA curve, probably because endothermic and exothermic reactions may be occurring simultaneously and the net heat is not sufficient to produce a thermal event. The mass loss up to $400{ }^{\circ} \mathrm{C}$ is in agreement with formation of $\mathrm{Mn}_{3} \mathrm{O}_{4}$ (Theor. $=62.79 \%, \quad \mathrm{TG}=62.79 \%$ ). The mass gain ( $\mathrm{TG}=0.56 \%$ ) that occurs between 475 and $544{ }^{\circ} \mathrm{C}$ is attributed to the oxidation of $\mathrm{Mn}_{3} \mathrm{O}_{4}$ to $\mathrm{Mn}_{2} \mathrm{O}_{3}$ (Theor. $=61.50 \%$, $\mathrm{TG}=62.30 \%$ ), which was confirmed by $\mathrm{X}$-ray powder diffractometry. The last mass loss observed between 930 and $970{ }^{\circ} \mathrm{C}(1.81 \%)$, corresponding to an endothermic peak at $930{ }^{\circ} \mathrm{C}$, is attributed to the partial reduction of $\mathrm{Mn}_{2} \mathrm{O}_{3}$ to $\mathrm{MnO}$ (Theor. $=65.40 \%$, $\mathrm{TG}=64.11 \%)$ and in agreement with the literature [26].

Cobalt compound The simultaneous TG-DTA curves are shown in Fig. 5b. The thermal decomposition of the anhydrous compound occurs in two consecutive steps between $310-354$ and $354-383{ }^{\circ} \mathrm{C}$, with losses of 20.12 

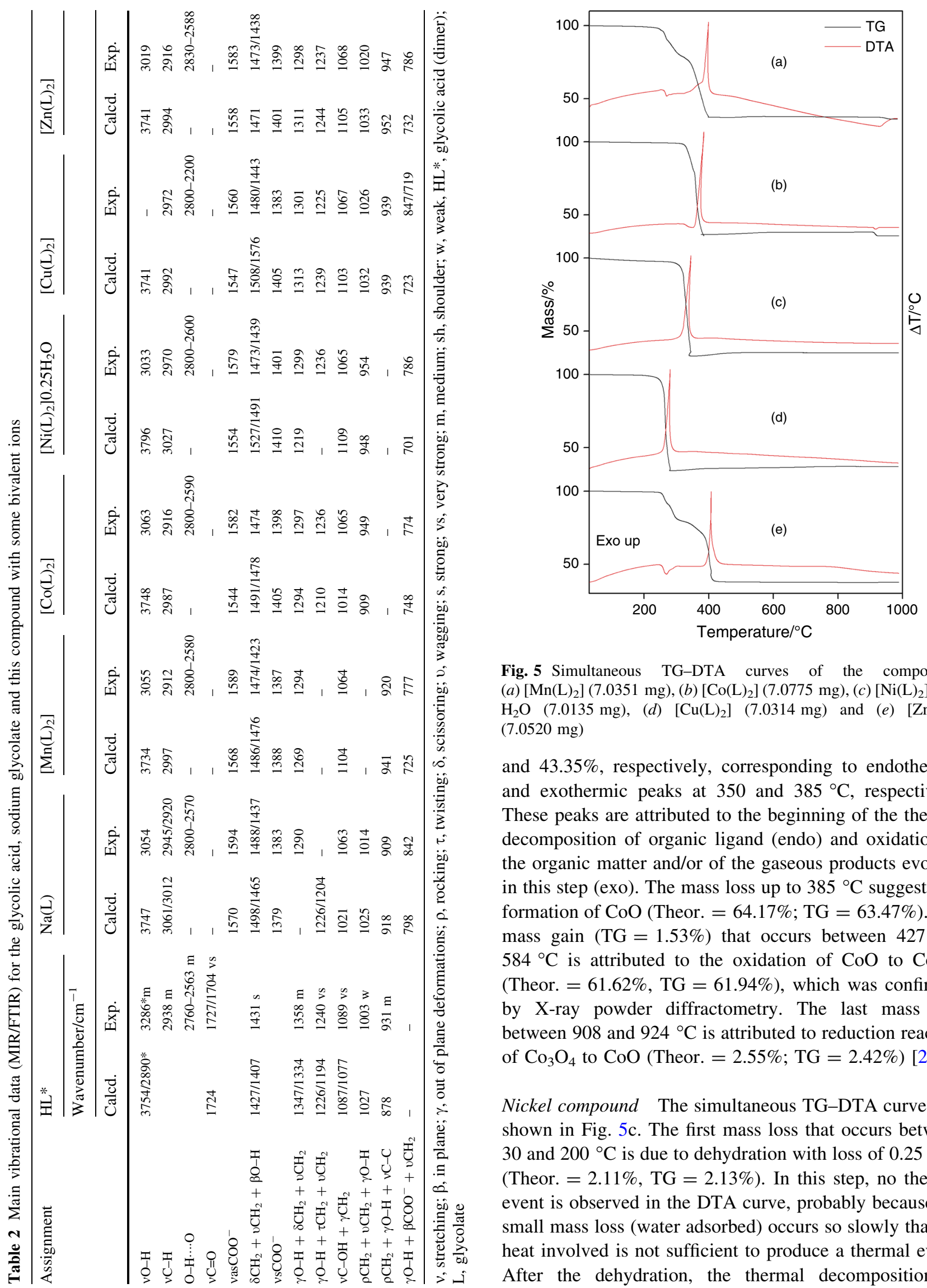

Fig. 5 Simultaneous TG-DTA curves of the compounds: (a) $\left[\mathrm{Mn}(\mathrm{L})_{2}\right](7.0351 \mathrm{mg}),(b)\left[\mathrm{Co}(\mathrm{L})_{2}\right](7.0775 \mathrm{mg}),(c)\left[\mathrm{Ni}(\mathrm{L})_{2}\right] 0.25-$ $\mathrm{H}_{2} \mathrm{O} \quad(7.0135 \mathrm{mg}), \quad(d) \quad\left[\mathrm{Cu}(\mathrm{L})_{2}\right] \quad(7.0314 \mathrm{mg})$ and $(e) \quad\left[\mathrm{Zn}(\mathrm{L})_{2}\right]$ (7.0520 mg)

and $43.35 \%$, respectively, corresponding to endothermic and exothermic peaks at 350 and $385^{\circ} \mathrm{C}$, respectively. These peaks are attributed to the beginning of the thermal decomposition of organic ligand (endo) and oxidation of the organic matter and/or of the gaseous products evolved in this step (exo). The mass loss up to $385{ }^{\circ} \mathrm{C}$ suggests the formation of $\mathrm{CoO}$ (Theor. $=64.17 \%$; $\mathrm{TG}=63.47 \%$ ). The mass gain $(\mathrm{TG}=1.53 \%)$ that occurs between 427 and $584{ }^{\circ} \mathrm{C}$ is attributed to the oxidation of $\mathrm{CoO}$ to $\mathrm{Co}_{3} \mathrm{O}_{4}$ (Theor. $=61.62 \%$, $\mathrm{TG}=61.94 \%$ ), which was confirmed by X-ray powder diffractometry. The last mass loss between 908 and $924{ }^{\circ} \mathrm{C}$ is attributed to reduction reaction of $\mathrm{Co}_{3} \mathrm{O}_{4}$ to $\mathrm{CoO}$ (Theor. $=2.55 \%$; $\mathrm{TG}=2.42 \%$ ) [27].

Nickel compound The simultaneous TG-DTA curves are shown in Fig. 5c. The first mass loss that occurs between 30 and $200{ }^{\circ} \mathrm{C}$ is due to dehydration with loss of $0.25 \mathrm{H}_{2} \mathrm{O}$ (Theor. $=2.11 \%, \mathrm{TG}=2.13 \%$ ). In this step, no thermal event is observed in the DTA curve, probably because the small mass loss (water adsorbed) occurs so slowly that the heat involved is not sufficient to produce a thermal event. After the dehydration, the thermal decomposition of 
(a)
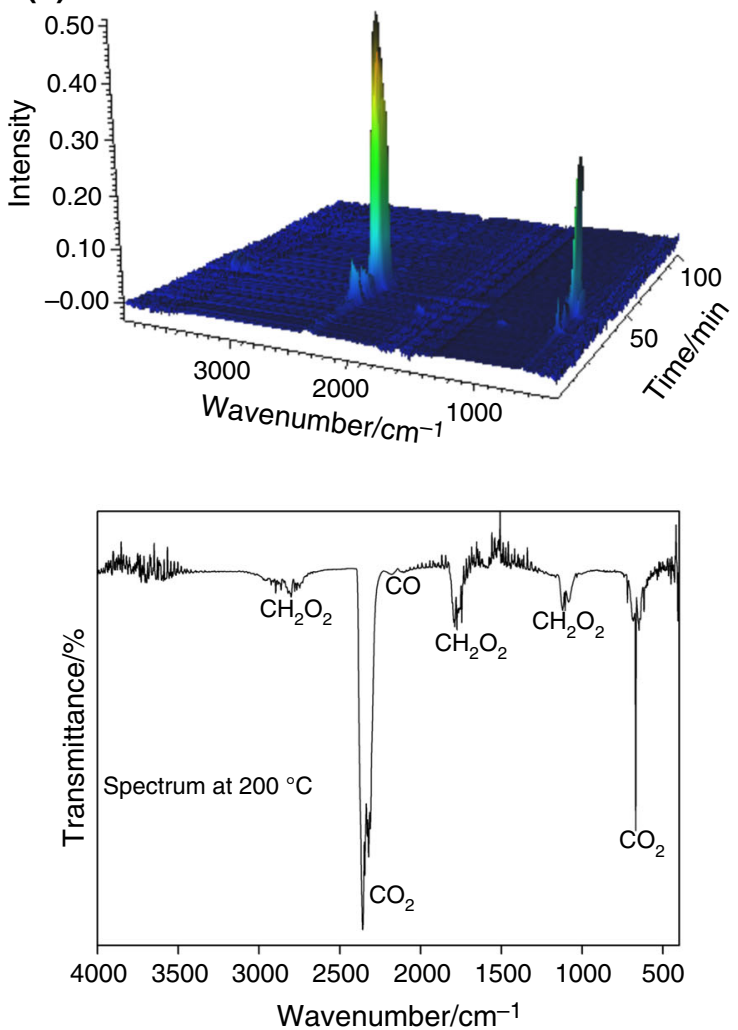

(b)
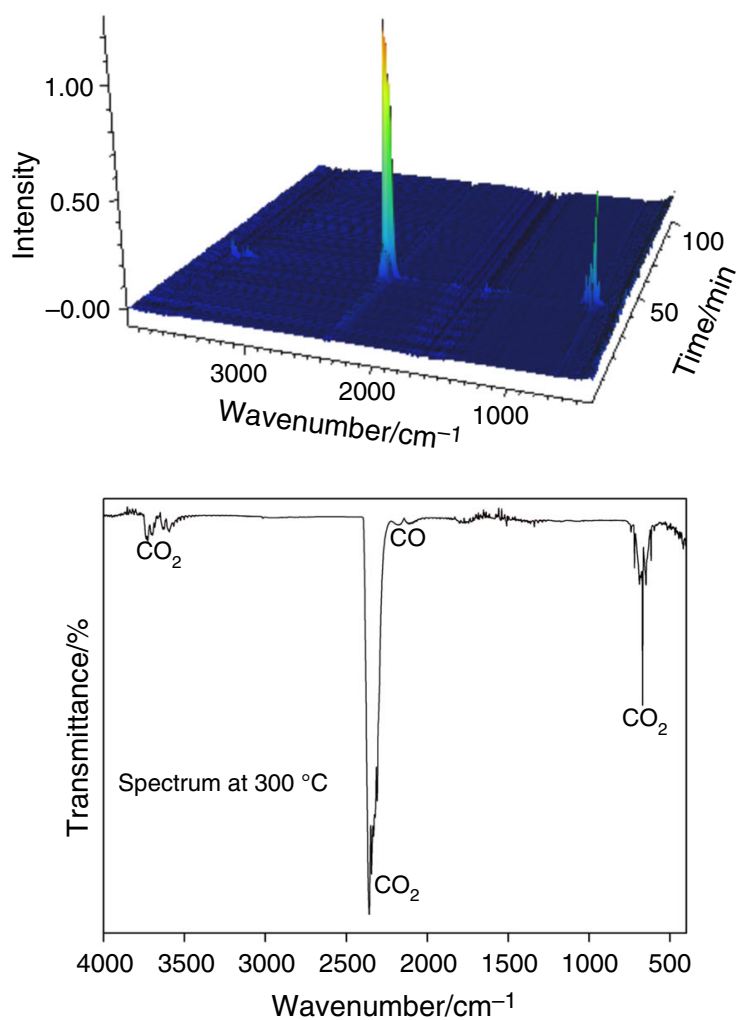

Fig. 6 IR spectra and 3D FTIR plot of the gaseous products evolved during the decomposition of the a manganese and $\mathbf{b}$ cobalt compounds

anhydrous compound occurs in a single step between 280 and $346{ }^{\circ} \mathrm{C}$ with loss of $65.16 \%$, corresponding to the exothermic peak at $345^{\circ} \mathrm{C}$ in DTA curve. This peak is attributed to the oxidation of the organic matter and/or of the gaseous products evolved during the thermal decomposition, with the formation of a mixture of $\mathrm{Ni}^{\circ}$ and $\mathrm{NiO}$ in no simple stoichiometric relation (Theor. $=72.48 \%(\mathrm{Ni})$, Theor. $=64.22 \%(\mathrm{NiO}), \mathrm{TG}=67.30 \%)$. The mass gain $(\mathrm{TG}=2.32 \%)$ that occurs between 362 and $506{ }^{\circ} \mathrm{C}$ is attributed to the oxidation reaction of $\mathrm{Ni}^{\circ}$ to $\mathrm{Ni}$ (II) with formation of $\mathrm{NiO}$ as the final residue (Theor. $=64.97 \%$, $\mathrm{TG}=64.97 \%$ ), which was confirmed by X-ray powder diffractometry.

Copper compound The simultaneous TG-DTA curves are shown in Fig. 5d. These curves show that the compound is anhydrous and stable up to $205{ }^{\circ} \mathrm{C}$. Above this temperature, the thermal decomposition occurs in a single step between 205 and $283{ }^{\circ} \mathrm{C}$ corresponding to the exothermic peak at $280{ }^{\circ} \mathrm{C}$ attributed to the oxidation of the organic matter and/ or of the gaseous products evolved during the thermal decomposition. The mass loss up to $283{ }^{\circ} \mathrm{C}$ is in agreement with the formation of $\mathrm{Cu}_{2} \mathrm{O}$ (Theor. $=66.20 \%$, $\mathrm{TG}=65.96 \%$ ). The mass gain observed between 283 and
$750{ }^{\circ} \mathrm{C}$ is attributed to the oxidation reaction of $\mathrm{Cu}_{2} \mathrm{O}$ to $\mathrm{CuO}$ (Theor. $=3.74 \%, \mathrm{TG}=2.95 \%$ ). The total mass loss up to $750{ }^{\circ} \mathrm{C}$ is in agreement with the formation of $\mathrm{CuO}$ as the final residue (Theor. $=62.52 \%$; $\mathrm{TG}=63.11 \%$ ), which was confirmed by X-ray powder diffractometry.

Zinc compound The simultaneous TG-DTA curves are shown in Fig. 5e. These curves show that the compound is anhydrous and stable up to $250{ }^{\circ} \mathrm{C}$. The thermal decomposition of the anhydrous compound occurs in three steps between $250-273,273-304$ and $304-430{ }^{\circ} \mathrm{C}$. The first two are overlapping ones, with losses of 8.78, 10.52 and $43.19 \%$, respectively, corresponding to endothermic peaks at $269{ }^{\circ} \mathrm{C}$ and $287{ }^{\circ} \mathrm{C}$ (shoulder) ascribed to the thermal decomposition. The exothermic peak at $407^{\circ} \mathrm{C}$ was attributed to the oxidation of the organic matter and/or of the gaseous products evolved during the thermal decomposition. The total mass loss up to $430{ }^{\circ} \mathrm{C}$ is in agreement with the formation of $\mathrm{ZnO}$ as the final residue (Theor. $=62.23 \%$; $\mathrm{TG}=62.49 \%$ ), which was confirmed by $\mathrm{X}$-ray powder diffractometry.

Evolved gas analysis (EGA) The gaseous products evolved during the thermal decomposition of the sodium 
and bivalent transition metal glycolates were monitored by FTIR, and the spectra of the gaseous products evolved during the thermal decomposition of manganese and cobalt compounds are shown in Fig. 6, as representative of all compounds. Based on the reference spectra database available in the equipment software, the main gaseous products identified were $\mathrm{CO}_{2}, \mathrm{CO}$ and formic acid (Mn and $\mathrm{Cu})$ or $\mathrm{CO}$ and $\mathrm{CO}_{2}(\mathrm{Na}, \mathrm{Co}, \mathrm{Ni}, \mathrm{Zn})$.

\section{Conclusions}

This paper presents a successful route for synthesis of compounds of glycolic acid with bivalent transition metal ions ( $\mathrm{Mn}, \mathrm{Co}, \mathrm{Ni}, \mathrm{Cu}$ and $\mathrm{Zn}$ ), the quantum chemical approach calculations to help suggest the molecular structures and its characterization by using different analytical techniques.

From TG, high-resolution mass spectrometry, complexometry and elemental analysis results, a general formula could be established for the synthesized compounds.

The infrared spectroscopic data are in good agreement with the theoretical calculations, which permitted to suggest that both hydroxyl and carboxyl groups act as coordination sites, as well as to determine the probable threedimensional structure of the compounds.

The simultaneous TG-DTA curves also provided previously unreported information about the thermal stability and thermal decomposition of these compounds. The monitoring of evolved gases showed that the thermal decomposition of metal glycolates occurs with release of formic acid, $\mathrm{CO}$ and $\mathrm{CO}_{2}$ for $\mathrm{Mn}(\mathrm{II})$ and $\mathrm{Cu}(\mathrm{II})$ compounds or $\mathrm{CO}$ and $\mathrm{CO}_{2}$ for $\mathrm{Na}, \mathrm{Co}(\mathrm{II}), \mathrm{Ni}(\mathrm{II})$ and $\mathrm{Zn}(\mathrm{II})$ ones.

Acknowledgements The authors thank FAPESP, CNPq and CAPES Foundation (Brazil) by financial support. This research was supported by resources supplied by the Center for Scientific Computing (NCC/ GridUNESP) of the Sao Paulo State University (UNESP), Instituto de Quimica de Araraquara, UNESP Campus de Araraquara.

\section{References}

1. Caires FJ, Lima LS, Gomes DJC, Gigante AC, Treu-Filho O, Ionashiro M. Thermal and spectroscopic studies of solid oxamate of light trivalent lanthanides. J Therm Anal Calorim. 2013;111:349-55.

2. Campos FX, Nascimento ALCS, Colman TAD, Gálico DA, TreuFilho O, Caires FJ, Siqueira AB, Ionashiro M. Synthesis, characterization and thermal behavior of solid state of some mefenamate of trivalent lanthanides ( $\mathrm{La}, \mathrm{Ce}, \mathrm{Pr}$ and Nd). J Therm Anal Calorim. 2016;123:91-103.

3. Grenthe I. Structural studies on rare earth carboxylates. Acta Chem Scand. 1972;26:1479-89.
4. Choppin GR, Degischer G. Complexing of trivalent actinide ions by glycolate. J Inorg Nucl Chem. 1972;34:3473-7.

5. Melikyan GG, Amiryan F, Visi M, Hardcastle KI, Bales BL, Aslanyan G, Badanyan SH. Manganese (II)/(III) glycolates: preparation, X-ray crystallographic study and application in radical cycloaddition reactions. Inorg Chim Acta. 2000;308: $45-50$.

6. Trombe JC, Jaud J, Galy J. Synthesis and structure of $\left[\mathrm{Ce}_{2}\left(\mathrm{H}_{2-}\right.\right.$ $\left.\mathrm{O})_{3}\right]\left(\mathrm{C}_{2} \mathrm{O}_{4}\right) 2.5\left(\mathrm{H}_{3} \mathrm{C}_{2} \mathrm{O}_{3}\right)$ and $\mathrm{Ce}_{2}\left(\mathrm{C}_{2} \mathrm{O}_{4}\right)\left(\mathrm{H}_{3} \mathrm{C}_{2} \mathrm{O}_{3}\right)_{4}$. J Solid State Chem. 2005;178:1094-103.

7. Das J, Evans IR, Khushalani D. Zinc glycolate: a precursor to ZnO. Inorg Chem. 2009;48:3508-10.

8. Guo C, Hu Y, Liu Y, Mu Y, Miau Y, Hu X. Synthesis of MWCNT/nickel glycolate polymer core-shell nanostructures and their nonenzymatic electrocatalytic activity toward glucose. Mater Chem Phys. 2011;130:10-3.

9. De Dobberlaere C, Mullens J, Hardy A, Van Bael MK. Thermal decomposition and spectroscopic investigation of a new aqueous glycolato (-peroxo) Ti(IV) solution-gel precursor. Thermochim Acta. 2011;520:121-33.

10. Lin XS, Sang YL, Sun WD, Yang SH. Assembly of three coordination polymers from glycolate ligands: synthesis, crystal structures and thermal properties. Transition Met Chem. 2013;38:503-9.

11. Flaschka HA. E.D.T.A. titrations and introduction to theory and practice. 2nd ed. Oxford: Pergamon Press; 1967.

12. de Oliveira $\mathrm{CN}$, Ionashiro $\mathrm{M}$, Graner CAF. Titulação complexométrica de zinco, cobre e cobalto. Ecl Quim. 1985;10:7-10.

13. Becke AD. Density-functional thermochemistry. 3. The role of exact exchange. J Chem Phys. 1993;98:5648-52.

14. Lee C, Yang W, Parr RG. Development of the colle-salvetti correlation-energy formula into a functional of the electrondensity. Phys Rev B. 1988;37:785-9.

15. McLean AD, Chandler GS. Contracted Gaussian-basis sets for molecular calculations. 1. 2nd row atoms, $Z=11-18$. J Chem Phys. 1980;72:5639-48.

16. Raghavachari K, Binkley JS, Seeger R, Pople JA. Self-consistent molecular orbital methods. 20. Basis set for correlated wavefunctions. J Chem Phys. 1980;72:650-4.

17. Gaussian 09, Revision A.02, Frisch MJ, Trucks GW, Schlegel HB, Scuseria GE, Robb, MA, Cheeseman JR, Scalmani G, Barone V, Mennucci B, Petersson GA, Nakatsuji H, Caricato M, Li X, Hratchian HP, Izmaylov AF, Bloino J, Zheng G, Sonnenberg JL, Hada M, Ehara M, Toyota K, Fukuda R, Hasegawa J, Ishida M, Nakajima T, Honda Y, Kitao O, Nakai H, Vreven T, Montgomery Jr. JA, Peralta JE, Ogliaro F, Bearpark M, Heyd JJ, Brothers E, Kudin KN, Staroverov VN, Kobayashi R, Normand J, Raghavachari K, Rendell A, Burant JC, Iyengar SS, Tomasi J, Cossi M, Rega N, Millam NJ, Klene M, Knox JE, Cross JB, Bakken V, Adamo C, Jaramillo J, Gomperts R, Stratmann RE, Yazyev O, Austin AJ, Cammi R, Pomelli C, Ochterski JW, Martin RL, Morokuma K, Zakrzewski VG, Voth GA, Salvador P, Dannenberg JJ, Dapprich S, Daniels AD, Farkas Ö, Foresman JB, Ortiz JV, Cioslowski J, Fox DJ. Gaussian, Inc., Wallingford CT, 2009.

18. Goodson DZ, Sarpal SK, Wolfsberg M. Influence on isotope effect calculations of the method of obtaining force constants from vibrational data. J Phys Chem. 1982;86:659-63.

19. Schelegel HB. Some practical suggestions for optimizing geometries and locating transition states. In: Juan B, Imre GC, editors. New theoretical concepts for understanding organic reactions. Netherlands: Academic; 1989. pp. 33-53.

20. GaussView, Version 5.0.8, Dennington, R.; Keith, T.; Millam, J. Semichem Inc., Shawnee Mission KS, 2000-2008.

21. Socrates G. Infrared characteristic group frequencies, vol. 91. 2nd ed. New York: Wiley; 1994. p. 236-7. 
22. Silverstein RM. Webster FX. Spectrometric identification of organic compounds. 6th ed. New York. 1998; 92-93, 96-97.

23. Deacon GB, Phillips RJ. Relationship between the carbon-oxygen stretching frequencies of carboxylate complexes and the type of carboxylate coordination. Coord Chem Rev. 1980;30:227-50.

24. Maffei RS, Esposito BP, Yokoyama-Yasunaga JKU, Miguel DC, Uliana SRB. Synthesis, characterization and evaluation of antileishmanial activity of copper (II) with fluorinaled $\alpha$-hidroxyisocarboxylate ligands. Biometals. 1969;22:1095-101.

25. Carballo R, Covelo B, Garcia-Martinez E, Vasquez Lópes EM, Castiñeiras A, Niclós J. The interaction of 2-methyllactic acid $(\mathrm{H} 2 \mathrm{~mL})$ with divalent metal cation: the structures of $\left[\mathrm{M}(\mathrm{HmL})_{2}\right]$ M = Mn(II), Zn (II). Polyhedron. 2003;22:1051-7.
26. Biernack L, Pokrzywnicki S. The thermal decomposition of manganese carbonate, thermogravimetry and exoemission if electrons. J Therm Anal Calorim. 1999;55:227-32.

27. Caires FJ, Lima LS, Carvalho CT, Ionashiro M. Thermal behavior of succinic acid, sodium succinate and its compound with some bivalent transition metals íons. Thermochim Acta. 2010;500:6-12. 